\title{
How are Mobile Makerspaces Utilized in Schools?
}

\author{
Megumi Iwata \\ Faculty of \\ Education \\ University of Oulu \\ Oulu Finland \\ megumi.iwata@stu \\ dent.oulu.fi
}

\author{
Kati Pitkänen \\ Faculty of \\ Education \\ University of Oulu \\ Oulu Finland \\ kati.pitkanen@stud \\ ent.oulu.fi
}

\author{
Jani Ylioja \\ Faculty of \\ Information \\ Technology and \\ Electrical \\ Engineering \\ University of Oulu \\ Oulu Finland \\ jani.ylioja@oulu.fi
}

\author{
Iván Sánchez \\ Milara \\ Faculty of \\ Information \\ Technology and \\ Electrical \\ Engineering \\ University of Oulu \\ Oulu Finland
}

\author{
Jari Laru \\ Faculty of \\ Education \\ University of Oulu \\ Oulu Finland \\ jari.laru@oulu.fi
}

\begin{abstract}
To explore diverse means to apply digital fabrication in formal education, this poster presents an overview of the literature regarding the use of mobile makerspaces in K-12 school contexts. Among the reviewed literature, mobile makerspace activities were integrated with school curriculums, especially in STEM fields, and teachers were highly involved in planning and implementing the activities. We noticed that technology experts support the activities as well as teachers' professional development by providing technical assistance. Our findings contribute to uncover the current practices of mobile makerspaces and call for in-depth scientific investigation.
\end{abstract}

\section{CCS CONCEPTS}

- K-12 Education • Applied computing• Computing education

\section{KEYWORDS}

Mobile makerspace; Mobile Fab Lab; digital fabrication; formal education; K-12 education; STEM.

\section{ACM Reference format:}

Megumi Iwata, Kati Pitkänen, Jani Ylioja, Iván Sánchez Milara, and Jari Laru. 2019. How are mobile makerspaces utilized in schools? In Proceedings of the Conference on Creativity and Making in Education (FabLearn Europe'19). ACM, New York, NY, USA, 2 pages. https://doi.org/10.1145/3335055.3335069

\section{Introduction}

In this poster, we aim to explore the current practices of mobile makerspaces in K-12 school contexts. The previous studies claimed benefits of applying digital fabrication in education [e.g., [1],[10],[11]]. Blikstein [[1]] emphasized the needs for

\footnotetext{
Permission to make digital or hard copies of part or all of this work for personal or classroom use is granted without fee provided that copies are not made or distributed for profit or commercial advantage and that copies bear this notice and the full citation on the first page. Copyrights for third-party components of this work must be honored. For all other uses, contact the Owner/Author.

FabLearn Europe '19, May 28-29, 2019, Oulu, Finland

(C) 2019 Copyright is held by the owner/author(s).

ACM ISBN 978-1-4503-6266-5/19/05.

https://doi.org/10.1145/3335055.3335069
}

implementing digital fabrication at schools for the sake of equal participation. Although machines for digital fabrication are getting more and more affordable, not all schools are able to equip those facilities. Some schools visit makerspaces in their communities, but the physical distance and accessibility are still problematic.

To confront this situation, community organizations, such as schools, libraries and universities, have started mobile makerspaces. Mobile makerspaces are described broadly as "maker locations that can move" [[7]]. Regardless of the forms, including wagon, car, cart or bus, mobile makerspaces provide transportable set of tools for digital fabrication [[7]]. Mobile makerspaces in communities (e.g., a vehicle with tools goes to different schools in the community) allow schools to apply digital fabrication without preparing special facilities. Mobile makerspaces in schools (e.g., a cart with tools which can be transferred in different classrooms) enable schools to implement digital fabrication activities flexibly in different locations. The previous studies noted that it is important to integrate activities in school curriculum [[9]] and involve teachers $[[10],[11]]$ in order to utilize digital fabrication in school contexts. In this paper, we focus on how mobile makerspaces are integrated with school curriculum, as well as how teachers and technology experts (e.g., organizers of mobile makerspaces) are involved in the process.

\section{Research Methods}

We employed narrative literature review. Narrative literature review is used to describe and summarize the current state of emerging issues [[4]]. We applied Boolean search with keywords of "mobile makerspace", "mobile Fab Lab" and "mobile FabLab" on $15^{\text {th }}$ of February 2019. We found 291 articles which include the keywords in title, abstract or keywords (EBSCO: 3, Elsevier: 3, IEEE: 1, ProQuest: 23, SCOPUS: 16, Springer: 7, Web of Science: 10, and Google Scholar: 228). In this study, we focused on scientific literature regarding mobile makerspaces in K-12 school contexts. Thus, we excluded non-scientific articles (e.g., an online article in a project website), articles without implementation of the activities (e.g., an article introducing tools of a mobile makerspace) and articles without descriptions of the activities in K-12 schools (e.g., an article describing mobile makerspace activities for university students or general public in a community). After excluding those articles, we reviewed the five articles for this study. 


\section{Findings}

Table 1 summarizes the overview of the reviewed literature. All the literature introduced the mobile makerspace activities implemented during the school hours.

Table 1. Overview of mobile makerspaces in the literature

\begin{tabular}{|c|c|c|c|}
\hline Authors & Type & Organizer & Students \\
\hline Compeau [[2]] & $\begin{array}{l}\text { Vehicle } \\
\text { type }\end{array}$ & $\begin{array}{l}\text { Organization at } \\
\text { university }\end{array}$ & $3^{\text {rd }}-8^{\text {th }}$ grade \\
\hline Craddock [[3]] & $\begin{array}{l}\text { Vehicle } \\
\text { type }\end{array}$ & $\begin{array}{l}\text { High school } \\
\text { library }\end{array}$ & $\begin{array}{l}\text { Elementary \& } \\
\text { middle school }\end{array}$ \\
\hline $\begin{array}{l}\text { Gale, Cappelli } \\
\& \text { Bryant }[[5]]\end{array}$ & Cart type & School & $3^{\text {rd }}-8^{\text {th }}$ grade \\
\hline $\begin{array}{l}\text { McKay \& } \\
\text { Peppler [[6]] }\end{array}$ & Cart type & Researchers & K-8 \\
\hline O'Connell [[8]] & Cart type & University & K-8 \\
\hline
\end{tabular}

\subsection{Integration with School Curriculum}

In the reviewed literature, mobile makerspace activities were integrated with STEM (science, technology, engineering, and math) subjects. The activities included creating a paper circuit [[3]], developing robots using various electronics tools [[5]], and designing a wearable technology with a microcontroller [[2]]. Students engaged not only in interacting with digital technology, but also in design thinking and iterative design processes [[5]]. Such processes included identifying a problem, researching and designing potential solutions, developing and testing prototypes, and sharing designs with the school community [[5]]. Mobile makerspace activities increased students' interests in STEM fields and enhanced diversity in STEM fields, such as choosing computer class as an optional subject [[2]].

The reviewed literature introduced mobile makerspace activities associated with different subjects, such as designing and 3D printing historical objects in a history class [[3]] and digital story telling in craft and art class [[5]]. Students also used mobile makerspaces for interest-driven class period which was open and play oriented class in part conceived by students, in part guided and developed by teachers [[6]]. The activities included DIY Sound Studio to visualize sounds as vibration, and Interactive Book Project using digital tools [[6]]. Also, students used mobile makerspace for school events, such as presenting original innovations towards real-world problems in Science and Engineering Faire or making banners for their fall market [[5]].

\subsection{Teachers' and Technology Experts' Roles}

Technology experts who organized Mobile makerspaces provided training for teachers [[3],[5],[8]]. In the training, technology experts explained how to use the machines and software and introduced example projects which made it easier for the teachers to plan the activities suitable for their curriculum [[5]]. In the training session, teachers got familiar not only with tools and materials, but also problem-solving approach in engineering [[8]].
Although the ways of planning the lessons varied among the literature, the reviewed literature mentioned that teachers were actively involved in planning the lessons [[2],[3],[5],[8]]. Teachers planned the lessons to utilize mobile makerspaces effectively for students' learning [[5]]. Compeau [[2]] explained that the technology experts of the mobile makerspace planned lessons and activities carefully with educators in different grades before going around the schools. The educators provided comments of activities' ability to engage students, increasing association with the STEM fields, and increasing diversity in STEM fields [[2]].

The reviewed literature introduced that teachers took control over the lessons, while technology experts assisted teachers with technical support [[3],[5]]. Technical support included, for instance, solving a problem of 3D printer which did not work because of a wrong filament [[5]]. Teachers and technology experts divided the roles in the activities. For example, technology experts provided technical knowledge of actual making of a paper circuit, while the teacher focused on explaining the contents in the curriculum [[3]]. Craddock [[3]] illustrated that especially in elementary schools, activities needed to be more structured compared to the middle schools. Such activities were guided by teachers and highly tied with school curriculum while activities in middle schools had more flexibility and technology experts played bigger roles [3].

\section{Discussion}

In the reviewed literature, several activities were planned and organized by teachers and integrated in the curriculums, especially STEM fields. Integration of digital fabrication activities and teachers' active involvement in the planning and implementing of the activities may enhance applying digital fabrication in formal education. On the other hand, when schools use mobile makerspaces, activities may need to be structured and standardized, as: 1) tools and resources are limited compared to visiting located makerspaces, and 2) in order to reserve mobile makerspaces, teachers have to plan the activities and the best practice to include them into curriculums. Communication and collaboration between teachers and technology experts, such as division of roles, may be essential to implement mobile makerspace activities in schools.

\section{Conclusion}

In this poster, we reviewed the five articles regarding the current practices of mobile makerspaces in K-12 school contexts. We found mobile makerspace activities may increase students' interests of STEM subjects and enhance teachers' professional development in STEM fields. However, we noticed that the number of the literature about implementation of mobile makerspaces activities in K-12 school context is very limited. In-depth scientific investigations towards the use and benefits of mobile makerspaces are crucial to apply mobile makerspace activities at schools. For the future study, we suggest expanding keywords for searching the literature by adding, for instance, "transportable" or "maker tool 


\section{How are Mobile Makerspaces Utilized in} Schools?

kits," in order to reach all the possible literature with broader definitions of mobility.

\section{REFERENCES}

[1] Paulo Blikstein. 2013. Digital Fabrication and 'Making' in Education: The Democratization of Invention. In FabLabs: Of Machines, Makers and Inventors J. Walter-Herrmann \& C. Büching (Eds.). Transcript Verlag, Germany, 1-21.

[2] Sccot Compeau. 2018. Designing a mobile makerspace: A strategy for increasing diversity by offering engineering outreach workshops to underrepresented youth. In Proceedings of the Canadian Engineering Education Association (CEEA)

[3] IdaMae L. Craddock. 2015. Makers on the move: A mobile makerspace at a comprehensive public high school. Library Hi Tech, 33, 4: 497-504. http://doi.org/10.1108/LHT-05-2015-0056

[4] Bruce B Frey. 2018. The SAGE encyclopedia of educational research, measurement, and evaluation (Vols. 1-4). SAGE Publications, Inc. https://doi.org/10.4135/9781506326139

[5] Jessica D. Gale, Christopher Cappelli, Courtney Bryant. 2017. Program Evaluation-STEAM Trunks: Enhancing K-8 Project-Based Learning through Mobile Makerspaces. In 2017 ASEE Annual Conference \& Exposition.

[6] Christian McKay, Kylie Peppler. 2013. MakerCart: A mobile fab lab for the classroom. In Position Paper at the Interaction Design for Children Conference (IDC).

[7] Heather M. Moorefield-Lang. 2015. When makerspaces go mobile: Case studies of transportable maker locations. Library Hi Tech, 33, 4: 462-471.

[8] Brian P. O'Connell. 2016. Implementation of a Mobile Makerspace in a K-8 School (Work in Progress). In 2016 ASEE Annual Conference \& Exposition.

[9] Kevin M. Oliver. 2016. Professional Development Considerations for Makerspace Leaders, Part One: Addressing "What?" and "Why?". TechTrends, 60, 2: 160-166. https://doi.org/10.1007/s11528-016-0028-5

[10] Kati Pitkänen, Megumi Iwata. 2019. What are the premises and the essential elements of activity design for applying digital fabrication in formal education? Master's thesis. University of Oulu, Oulu, Finland.

[11] Rachel C. Smith, Ole S. Iversen, Rune Veerasawmy. 2016. Impediments to digital fabrication in education: A study of teachers' role in digital fabrication. International Journal of Digital Literacy and Digital Competence, 7, 1: 33-49. https://doi.org/10.4018/ijdldc.2016010103
FabLearn Europe'19, May, 2019, Oulu, Finland 